\title{
Investigating the relationships between service capabilities and financial statements indicators
}


Throughout Europe, PLs have had a decade-long metamorphosis. 'Freight transport by road' industry (SIC code 49410) is moving from a highly fragmented to a more concentrated one. ${ }^{13,14}$ In the U.K., according to a 2016 report of the National Bureau of Statistics, this has resulted in both the firm's average fleet size and number of employees increasing by $35 \%$, along with a $4 \%$ rise in the industry's share of GDP. These statistics confirm the important role this sector plays in the UK economy. ${ }^{10}$

Research has so far focused on PLs' supply chain management and operations. ${ }^{14-19}$ In comparison, PLs' service capabilities and their impact on performance indicators have received less attention. For example, Liu and Lyons ${ }^{20}$ found through a cross-sectional analysis that 3PLs with different service capabilities did not have different financial performances. Hofmann and Lampe ${ }^{21}$ used a crosscluster longitudinal analysis of financial statements data and found that PLs with different service capabilities (2PLs, 3PLs, 4PLs) and different SIC codes have differences in profitability and tangible assets. Liu and Lai, ${ }^{22}$ through a cross-sectional analysis, found that different levels of specific service capabilities (i.e., external capabilities) did not directly affect 3PL's financial performance. In contrast, Liu and Lyons ${ }^{20}$ and Liu and Lai ${ }^{22}$ used survey data (Likert scales) to proxy financial performance, whereas Hofmann and Lampe ${ }^{21}$ used financial statements data. To contribute to this line of research, this study uses a cross-sectional analysis to discuss the relationship between PLs' service capabilities and their financial statements indicators. ${ }^{11,20,23,24}$ Peculiar to this study is the analysis of financial statements data of different PLs (2-3-4 PLs) belonging to the same market, i.e. the U.K. SIC code 49410 ('freight transport by road').

The service capabilities offered by each PLs have been collected using content analysis on open secondary data (PL's websites), while the relationship between capabilities and indicators has been analysed through non-parametric statistics. Financial statements indicators have been broken into economic-financial (EF) and non-economic/financial (NEF) indicators. The former are indicators that directly relate to a firm's cash inflows and outflows (e.g., turnover), while the latter indicators are related to the firm's infrastructure (e.g., the number of employees).

By analysing within a particular SIC code how the differences in the range and type of service capabilities offered affects the firm's financial statements structure, this study will provide an empirical application of the Resource Based View (RBV). In fact, as the business is the same (i.e., the SIC code is the same), the variations in the indicators are due to the different ways in which the PLs organize and deploy their resources to offer specific service capabilities. ${ }^{1}$ Furthermore, this study will analyse the stratification of the U.K. road transport market and thus will appeal to all U.K.-based stakeholders, including managers and policy makers.
The research framework is explained in the next sections. Subsequently, the road transport firms' different combinations of service capabilities are derived and statistical analyses performed. A discussion of the results follows.

\section{Research framework}

\section{Theoretical background}

The Resource Based View (RBV) theorizes that firms compete by acquiring various resources through bundling these resources into capabilities and by leveraging such capability bundles into specific markets. ${ }^{1,2,25,26}$ Thus, RBV has been widely applied as a theoretical foundation to explain the existence of different capability bundles among logistics firms, as well as studying the effects of different combinations of capabilities on performance and nonperformance indicators. ${ }^{11,20,24}$

RBV adopters argue that PLs use various tangible and intangible resources to develop capabilities addressing specific customer needs. ${ }^{11,20,23}$ 'Resources', 'capabilities' and their combinations (i.e., strategies) are key RBV concepts. A resource is any 'asset or input to production (tangible or intangible) that an organization owns, controls or has access to on a semi-permanent basis' ${ }^{27}$ Resources are idiosyncratic attributes controlled by firms whose combination are the basis for their capability development. ${ }^{1,25}$ They can be classified into resources exploiting either tangible or intangible assets such as trucks or knowledge. ${ }^{20,28,29}$ Capabilities refer to "the ability of an organization to perform a coordinated set of tasks, utilizing organizational resources, for the purpose of achieving a particular result ${ }^{27}$ Capabilities are refined resources that cannot be traded. ${ }^{29,30}$ An example is the number of post-graduate employees, which can somewhat be 'traded', and the corresponding capability, which cannot be directly acquired on the market, namely the expertise of these employees. For PLs, 'capabilities' often refers to service capabilities, i.e. services offered to customers. ${ }^{24,31,32}$ This study uses this definition. Service capabilities can be further broken down into two other subgroups: basic service capabilities or 'low-scope service capabilities', and value-added service capabilities or 'broad-scope service capabilities'. ${ }^{21,33}$

Basic service capabilities refer to goods delivery that are part of the core activities of the logistics business such as product tracking, picking and packing, ${ }^{24}$ temperaturesensitive truck-loads, ${ }^{21}$ and contract distribution. ${ }^{11}$ Valueadded service capabilities refer to activities beyond those strictly related to goods delivery. These capabilities are based on tangible or intangible assets. ${ }^{11,24}$ Value-added service capabilities based on tangible assets include diagnostic services and truck customization, whereas capabilities based on intangible assets are often knowledge-intensive solutions such as project management, consulting, and advanced telematics. ${ }^{11,20,24,34-36}$ Different 
combinations of service capabilities give rise to different service strategies for the PLs'. ${ }^{21,32,37}$ In addition, groups of PLs with different service strategies give rise to different strategic groups. ${ }^{38}$

\section{Research hypotheses}

PLs have different service capabilities, and this affects their performance in various ways. Previous studies have explored some of the open questions related to this matter. For example, several studies have focused on an analysis of the service capabilities adopted by PLs, ${ }^{23,29,39}$ and the influence that these capabilities have on each another. ${ }^{12,40,41}$ Conversely, other studies have analysed the relationship between the deployment of certain service capabilities and the variations in key financial and nonfinancial indicators. ${ }^{22,28,38}$

In their study, Liu and Lyons ${ }^{20}$ categorized a sample of 3PLs according to the extent of their service capabilities concluding that there was no direct relationship between groups of PLs and financial performance. Similarly, Kuo et al. ${ }^{31}$ used a cluster analysis with PLs in the container shipping industry and found that clusters with different intensities of various service capabilities did not result in diverse financial performance. In these examples, service capabilities and financial performance have been measured using Likert scales. On the other hand, Hofmann and Lampe $^{21}$ grouped different PLs (2-3-4PLs) across various SIC codes (e.g., sea-freight, road transport, etc.) based on their type and range of service capabilities to analyse the variations in their financial statements data. They found that the PLs groups showed differences in indicators such as ROE, ROA, Current Ratio, yet they were similar in their capital structure (e.g., Equity Ratio, Financial Risk Assessment).

Based on this line of research, further studies have focused on PLs with specific knowledge-intensive service capabilities and their relationship to performance indicators. ${ }^{1,28}$ Results confirmed several of the RBV's hypotheses. That is, PLs with valuable capabilities that are difficult to imitate prosper in their specific market niches. ${ }^{2}$ Shang ${ }^{42}$ found that warehouse service capabilities, that are not difficult to copy, were not linked to better financial performance (Sales, Market Share, and Profit). In comparison, Karia et al. ${ }^{28}$ and Karia and Wong ${ }^{11}$ have shown that PLs exploiting service capabilities related to IT infrastructure and managerial expertise, that are difficult to copy, achieved better financial performance. Similar results were found for PLs exploiting knowledge-intensive service capabilities according to studies by Evangelista et al., ${ }^{32}$ Liu et al., ${ }^{29}$ Ellinger et al., ${ }^{12}$ Huang et al., ${ }^{43}$ and Ellinger et al. ${ }^{44}$

Scholars have recently indicated that additional research is necessary to explore the relationship between PLs with specific service capabilities and their financial statements indicators. $^{21,23}$ This study has responded to the call for additional research by focusing on PLs belonging to the 'freight transport by road' sector (SIC 49410). By using financial statements data, this study argues that there is no difference in economic-financial (EF) indicators among different PLs with diverse service capabilities. The rationale for this is that efficiency in the market niches within the SIC code 49410 would discourage the use of suboptimal strategies. ${ }^{1}$ However, according to RBV and earlier logistic research, this paper theorizes that PLs with distinctive knowledge-intensive service capabilities achieved better financial performance. ${ }^{8,11,28,45,46}$ Thus, the following two hypotheses have been developed:

$H_{1 a}$ : PLs belonging to the SIC code 49410 offering different combinations of service capabilities do not have diverse values in specific $E F$ indicators.

$H_{1 b}$ : PLs belonging to the SIC code 49410 offering knowledge-intensive service capabilities do not have different values in specific $E F$ indicators.

The first hypothesis examines the $E F$ indicators of PLs with different service capabilities. The second explores whether PLs with knowledge-intensive capabilities have superior $E F$ indicators. Both hypotheses have been formulated as null-hypotheses, with both being tested as two-tailed to reduce Type I errors, according to the recommendations by Fleiss et al. ${ }^{47}$

Different service capabilities depend upon specific tangible and intangible resources, ${ }^{23,48}$ such as using qualified employees for consulting services, and software engineers and RFID sensors for routing services. PLs' non-economic/ financial (NEF) indicators have been rarely used in the logistic literature. Hofmann and Lampe ${ }^{21}$ are among the few scholars that analysed the differences in NEF indicators among heterogeneous PLs. They found that PLs with different service capabilities, such as sea freight and railway trucking, have different NEF values. This further substantiated RBV theory, according to which firms will differ in their resources even if they are in the same industrial sector. ${ }^{1,2,49,50}$ In fact, firms with different combinations of service capabilities use a variety of resources and subsequently have different NEF financial statements indicators. ${ }^{11}$ This study argues that PLs with the same SIC code and different service capabilities have different NEF indicators. Hence, the following hypothesis is presented:

$\mathrm{H}_{2}$ : PLs with different combinations of service capabilities do not have different values in their NEF indicators.

Here again, as in the two hypotheses stated earlier, this hypothesis has been expressed in terms in the null form.

\section{Research methodology}

Service capabilities can be found and financial/nonfinancial indicators can be measured through primary or secondary sources. ${ }^{40}$ Liu and Lyons ${ }^{20}$ surveyed a sample 
of 3PLs regarding their service capabilities using a Likert Scale (Scale 1-7) based on the axes of capability ' $x$ ' and intensity ' $y$ '. In contrast, Wong and Karia ${ }^{23}$ have taken resource bundles from the PLs' profiles available on the web. Shang ${ }^{42}$ used a survey to study the impact of integration and organizational learning capabilities based on the PLs' performance. As recommended by several scholars, when available, secondary objective data should be used. $^{20,51,52}$

In this study, the different PLs in the 49410 sector have been identified by content analysis of open secondary data, namely PL's websites. ${ }^{53}$ Similar uses of content analysis have been already applied to logistics, ${ }^{21,23}$ road transport, ${ }^{44}$ and website analysis. ${ }^{54,55}$ The evaluation of $H_{1 a}, H_{1 b}$ and $\mathrm{H}_{2}$ was based on a series of non-parametric tests applied to the PLs' financial statements indicators. ${ }^{56,57}$ KruskalWallis tests were used to investigate the variations between the groups, whereas Mann-Whitney tests were applied for the same purpose between combinations of PL groups. ${ }^{20,24}$ In Table 1 a sketch of the analysis is reported. Details are provided in the following sections.

Table I. Research methodology.

\section{Steps I-2: Sample Selection and Grouping of the firms}

Selection of sector and country;

Collection of the companies.

Definition of the types of service capabilities provided by freight transport by road PLs;

Identification of the capabilities provided by each PL under each type (Content Analysis);

Assignation of each PL firm to a cluster based on number and type of service capabilities.

Steps 3-4: Indicators Selection and Statistical Analysis

Selection of the Economic/Financial (EF) Indicators;

Selection of the Non-Economic/Financial (NEF) Indicators.

Group level differences in the EF and NEF indicators (Kruskal-Wallis test);

Couple level differences in the EF and NEF indicators (Mann-Whitney test).

\section{Grouping of the firms}

\section{Sample selection}

The same country and industry (ceteris paribus) have been used to remove contingent factors when analysing variations in the PL groups. 1,3,25 Freight transport by road has been chosen because it is a key sector in all developed economies. ${ }^{10}$ The U.K. was chosen for analysis as it has an excellent infrastructure for freight transport. ${ }^{58-62}$ Furthermore, it is an island; therefore it is a good environment to further limit the effect of contingent factors. The PLs have been selected from the Financial Analysis Made Easy (FAME) database, a Bureau van Dijk product (Table 2).

Several PLs that were classified with the SIC code 49410 have been queried. Those with a limited road transport business, such as PLs offering mere relocation services, have been excluded from this study because they are outliers, in terms of their service strategy, with respect to the targeted sample. In the final sample, there were 76 PLs. Analogous studies have used the same database and analysed a similar number of PLs. ${ }^{20}$

\section{Identification of the service capabilities within each company}

PLs (2-3-4 PLs) have been classified according to the service capabilities they offer. ${ }^{21,33}$ Service capabilities were identified through content analysis of each PL's website. This procedure is necessary because, contrary to the SIC code, which is assigned univocally based on the major source of value added (or, as is often the case, turnover), there is no similar procedure to assign an 'nPL' code to a company. Service capabilities have been measured by assigning the word 'yes' if they could be identified in the PL's website; otherwise, 'no' was used. ${ }^{32}$

According to the recommendations by Dubois and Gadde, ${ }^{63}$ multiple rounds of websites' analyses have been performed. The first screening of the websites was

Table 2. Query and companies' footprint.

\section{Query}

UK SIC Code (2007

Classification):

Known value of:
49410

Turnover, Operating Profits, Number of Employees, Fixed Assets, Tangible Assets, Current Assets, Stock \& W.I.P., Working Capital, Net Cash In(Out) from Operating Activities, Return on Capital Employed (ROCE).

Total number of companies: 76

\begin{tabular}{llcccccc}
\hline Turnover & & & & & & \\
Percentile: & Min & $10 \%$ & $25 \%$ & $50 \%$ & $75 \%$ & $90 \%$ & Max \\
kf: & 4,548 & 7,669 & 9,398 & 12,055 & 22,641 & 81,412 & $1,147,400$ \\
\hline N. Employees & & & & & & & \\
Percentile: & Min & $10 \%$ & $25 \%$ & $50 \%$ & $75 \%$ & $90 \%$ & Max \\
N: & 50 & 62 & 87 & 116 & 242 & 577 & 17070 \\
\hline
\end{tabular}


performed using a list of service capabilities extracted from a series of highly ranked research papers. ${ }^{1,20,24,64-74}$ Then, following the procedure adopted by Cassell and Symon, ${ }^{75}$ multiple rounds of examinations of the PL websites were performed and a list of capabilities specific to the companies selected in the sample was developed. Service capabilities were then placed in one of the three category types: basic service capabilities, value-added capabilities based on tangible resources, and value-added capabilities based on intangible resources. Attention was also given to the most appropriate labels for each service capability. This is common practice in content analysis applications when refining and standardizing the coding tool for the analysis. ${ }^{53,76}$ It is also useful in a later stage of the analysis when external coders are involved. After three rounds of website examination, the authors agreed on the classification, a point referred to in the literature of content analysis as theoretical saturation. ${ }^{76}$ The process was finalized by revising the list of service capabilities with two external experts, as suggested by Ellinger et al. ${ }^{44}$ and Creswell and Miller. $^{77}$

Table 3 indicates the identified service capabilities in the sample and their definitions by giving some examples that are useful for their identification. The service capability type $\left(\mathrm{T}_{\mathrm{i}}\right)$ definition is cited on top of each of the groups.

The reliability of the service capability assignation of each company (Appendix 1) was tested with an external coder (an experienced researcher with a background in transportation research). The coder had to decide on a sub-sample of PLs whether or not ('yes/no' scale), based on the content of their website, each PL provided any of the 12 service capabilities shown in Table $3 .^{78}$ For this analysis, the coder was provided with Table 3 as a coding tool. At the end of the process, the outcome was compared with Table 1A (Appendix 1) through a 'percentage agreement' criterion. That is a measure of the total number of pairwise agreements between author's and coder's identifications. ${ }^{79}$ The outcome of the test $(93 \%)$ was found to be above Kassarjian's ${ }^{79}$ recommended standard (85\%), therefore the assignations in Table 1A were considered reliable.

\section{Formation of the $n P L s$ groups}

After the identification of the service capabilities offered by each company, it was necessary to assign the company to an ' $\mathrm{nPL}$ ' group (2PL, 3PL, 4PL). The assignation, as explained previously, was based on the service offering of each PL company. In particular, when analysing the 12 service capabilities, four out of seven groups emerged: $\left(T_{1}\right),\left(T_{1}+T_{2}\right),\left(T_{1}+T_{3}\right)$ and $\left(T_{1}+T_{2}+T_{3}\right)$. This meant that, for example, no firm had its service capabilities only in the $T_{2}, T_{3}$, or $T_{2}+T_{3}$ groups. The defined PL groups were found to have two main issues. First, they were fuzzy. Precise boundaries needed to be set to investigate the research hypotheses. In fact, by looking at the service capabilities provided by each firm in Appendix 1, one needs to ask whether firms offering one service in $T_{1}$ and one in $T_{2}$ and firms offering three services in $T_{1}$ and three in $T_{2}$ should be assigned to the same 'nPL' group or to different ones. In other words, the question arises about what should be the number of services per type to belong to a specific ' $n P L$ ' group. In this study, as suggested by Liu and Lyons, ${ }^{20}$ it is established that to belong to one of the four groups $\left(\mathrm{T}_{1} ; \mathrm{T}_{1}+\mathrm{T}_{2} ; \mathrm{T}_{1}+\mathrm{T}_{3} ;\right.$ and $\left.\mathrm{T}_{1}+\mathrm{T}_{2}+\mathrm{T}_{3}\right)$, a firm must provide at least two service capabilities for each $T_{i}$ peculiar to that group. For example, a firm offering two $T_{1}$ services and two $T_{2}$ services belongs to a group (the $T_{1}+$ $T_{2}$ group), whereas a firm providing three $T_{1}$ services and one $\mathrm{T}_{2}$ service does not.

As for the combinations of the service capabilities, as noted, they are four rather than three (the 'canonical' 2-34PLs). $T_{1}$ and $T_{1}+T_{2}$ could be put together, as firms in both groups are evidently 2PLs. Yet, for the sake of extracting more information, the analysis was performed in two ways: 1) by placing PLs with $T_{1}$ and $T_{1}+T_{2}$ service capabilities in the same group; and 2) by keeping them separate. The first group of firms has been labelled 2PLs, while the second $2+$ PLs to indicate haulage companies with additional asset intensive services. Table 4 reports the grouping of the PLs in Appendix 1 according to the explained criteria.

\section{Financial statements analysis}

\section{Choice of the indicators}

The financial statements indicators in Table 5 are based on the rationale that service capabilities are derived from the process of delivering products in a way that creates added value to customers by means of tangible and intangible resources. $^{20,42,80,81}$

NEF indicators such as Fixed Assets, Current Assets, etc. have already been used to analyse differences between firms engaging in different businesses. ${ }^{82,83}$ They have also been used to investigate the financial statements structure of PLs. ${ }^{21}$ On the other hand, the EF indicators have been used by Liu and Lyons ${ }^{20}$ and Lai, ${ }^{24}$ through primary rather than secondary data, to investigate the relationship between 3PLs with different service capabilities and financial performance. Overall, the indicators represent an agreement based upon choice to examine the financial and nonfinancial structure of 'nPLs'.

\section{Kruskal-Wallis and Mann-Whitney tests: Differences between the PLs groups}

Appendix 2 reports the first four moments of each indicator's distribution and the results of the Levene's test for variance homogeneity. It can be seen that the data did not meet the assumption for parametric tests such as ANOVA and t-tests, a well-known fact for financial statements data. ${ }^{84}$ For this reason, Kruskal-Wallis and Mann- 
Table 3. Service capabilities in the UK freight transport by road (SIC 494I0).

\begin{tabular}{|c|c|c|}
\hline \multicolumn{2}{|c|}{ Service Capabilities Definition } & Excerpts to identify the service \\
\hline \multicolumn{3}{|c|}{$\begin{array}{l}\text { TI: Basic service capabilities common to the majority of logistic companies. The core activity supported by these capabilities is a basic } \\
\text { storage and flow of goods from site A to site B. }\end{array}$} \\
\hline $\begin{array}{l}\text { Basic Warehousing } \\
\text { Services }\end{array}$ & $\begin{array}{l}\text { Services enabling a basic level of warehousing like } \\
\text { picking, packing, wrapping, and relabelling. }\end{array}$ & $\begin{array}{l}\text { 'We can offer storage in a clean, dry, fully racked } \\
\text { warehouse'; 'Flexible modern ambient } \\
\text { warehousing... Pick and pack'; }\end{array}$ \\
\hline Tracking Services & $\begin{array}{l}\text { Various services enabling the tracking of the products } \\
\text { from initial consignment to final delivery. }\end{array}$ & $\begin{array}{l}\text { 'Every one of our vehicles is fitted with the Quartix } \\
\text { Satellite Tracking System'; 'travel in a secure tracked } \\
\text { environment'; 'vehicle and load track and trace' }\end{array}$ \\
\hline $\begin{array}{l}\text { Specialized } \\
\text { Transport } \\
\text { Services }\end{array}$ & $\begin{array}{l}\text { Services enabling the transportation of particular } \\
\text { products like temperature controlled food, } \\
\text { hazardous materials or abnormal loads. }\end{array}$ & $\begin{array}{l}\text { 'we provide a highly dependable part load } \\
\text { solution ... and rigid vehicles offering payloads up to } \\
\text { I5 tonnes'; 'specialist liquid road tankers'; 'safe } \\
\text { transportation of hazardous loads' }\end{array}$ \\
\hline Contract Solutions & $\begin{array}{l}\text { Services enabling a priori agreement of tailored } \\
\text { packages for customers. }\end{array}$ & $\begin{array}{l}\text { 'servicing distribution contracts for some very large } \\
\text { customers allows us to offer tailored packages'; '[We] } \\
\text { offer a complete range of solutions } \\
\text { including... Contract Distribution' }\end{array}$ \\
\hline
\end{tabular}

T2: Service capabilities whose focus is the exploitation of the tangible resources of a logistics company.

Workshop Service offering facilities for the repair and maintenance 'modern Workshop and Vehicle recovery services';
Facilities of third-party fleets.

'We also have dedicated engineering workshops'; 'The facilities allow [us] to carry out all maintenance in-house for trucks, trailers and small plant machinery as well as maintenance and repairs for customers'

Diagnostic Services Services offering diagnostics and testing to third-party fleets.
Additional Additional services on the tangible assets of a logistics Equipment and company, like truck rental/personalization and Facility Services storage room rental.
Environmental Services focused on environmental aspects of the Services logistics business, like waste management/ transportation and products recycling.

'full testing services'; 'Driver CPC periodic training'; 'we provide MOT testing for external customers'

'some tractors bearing the livery of our customers'; '[Vehicles] can be supplied in the customer's own livery'; 'if required when you buy a second-hand vehicle from us, we'll paint the vehicle in your livery colours'

'Full Waste Carrier Licence'; '[We offer a complete] dismantling/removal service'; '[We provide] a range of transport services for the environmental waste sector with specialist equipment that includes waste tankers, hook-lifts, tippers and walking floor trailers'

T3: Service capabilities supporting customer's needs from a knowledge-intensive perspective.

$\begin{array}{ll}\begin{array}{c}\text { Consulting } \\ \text { Services }\end{array} & \begin{array}{c}\text { Services aimed to improve the business of the } \\ \text { customers, beyond the logistics side, like project } \\ \text { management. }\end{array} \\ \begin{array}{l}\text { Advanced } \\ \begin{array}{l}\text { Warehousing } \\ \text { Services }\end{array}\end{array} & \begin{array}{l}\text { Services improving the storage of customers' goods } \\ \text { from its very production (e.g. in-house JIT specialists) } \\ \text { to its proper storage and shipment (management of } \\ \text { returns, product testing). }\end{array}\end{array}$

Advanced

Telematics

Solutions
Personalized IT software solutions enabling customers to monitor the logistics part of their business through a series of KPIs on trucks, deliveries and stock.
Advanced Training Educational services addressed to drivers, mangers
$\begin{array}{cl}\text { Academies } & \text { and operators of logistics companies. }\end{array}$ 'helping businesses to plan fulfilment strategies and keep delivery costs to a minimum'; 'complete range of integrated services to help you run your business in the most efficient cost effective manner'

'[WMS] [p]roviding numerous stock statuses such as freeze and release, quarantine, blocked, and held'; '[We] offer a highly skilled team of re-workers'; 'Full range of value-added services including: pick, packing and dispatch; electronic labelling; reworking; reconfiguration'

'Adjustments to the IT system can be made to ensure that all our customers' requirements'; 'KPIs tailored to your individual requirements'; '[We are] powered by Mandata software which ensures our total control of your product from the moment we receive through any storage period and on to their distribution to your customers'

'Managing safely (IOSH) is a course for managers and supervisors ... Working Safely (IOSH) a one-day course for non-supervisory or managerial staff; 'training centre has been developed to offer training solutions for the transport and storage industries'; ' $[\mathrm{We}]$ offer a wide variety of industry related training courses' 
Table 4. PLs in the UK freight transport by road (SIC 494I0).

\begin{tabular}{|c|c|c|c|}
\hline PLs & $\begin{array}{l}\text { Service Types (at least two } \\
\text { services in each type } T_{i} \text { ) }\end{array}$ & $\%$ Companies & Brief Description \\
\hline 2PLs & TI & $42 \%$ & PLs offering basic haulage service capabilities. \\
\hline $2+\mathrm{PLs}$ & $\mathrm{TI}+\mathrm{T} 2$ & $20 \%$ & $\begin{array}{l}\text { PLs offering basic haulage service capabilities and providing additional value- } \\
\text { added capabilities exploiting their tangible resources. }\end{array}$ \\
\hline 3PLs & $\mathrm{TI}+\mathrm{T} 3$ & $26 \%$ & $\begin{array}{l}\text { PLs offering basic haulage service capabilities and providing additional value- } \\
\text { added capabilities exploiting their intangible resources. }\end{array}$ \\
\hline 4PLs & $\mathrm{T} 1+\mathrm{T} 2+\mathrm{T} 3$ & $12 \%$ & PLs offering a fully-integrated package of logistics service capabilities. \\
\hline
\end{tabular}

Table 5. EF and NEF indicators.

Economic/Financial Indicators:

Turnover, Operating Profits, Cash In (Out) from Operating Activities, Return on Capital Employed (ROCE).

Non-Economic/Financial Indicators:

Number of Employees, Fixed Assets, Tangible Assets, Current Assets, Stock \& W.I.P., Working Capital.

Table 6. Kruskal-Wallis and Mann-Whitney tests.

\begin{tabular}{|c|c|c|c|c|c|c|c|c|c|c|c|c|c|c|c|c|}
\hline \multirow{2}{*}{\multicolumn{3}{|c|}{$\frac{\mathrm{K} 4}{\text { Economic/Financial Ind. }}$}} & \multicolumn{2}{|c|}{$\begin{array}{c}\mathrm{K} 2 \\
(2-2+\mathrm{PLs}-3-4 \mathrm{PLs})\end{array}$} & \multicolumn{2}{|c|}{$\begin{array}{c}\mathrm{K} 2 \\
(2 \mathrm{PLs}-3 \mathrm{PLs})\end{array}$} & \multicolumn{2}{|c|}{$\begin{array}{c}\mathrm{K} 2 \\
(3 \mathrm{PLs}-4 \mathrm{PLs})\end{array}$} & \multicolumn{2}{|c|}{$\begin{array}{c}\mathrm{K} 2 \\
(2 \mathrm{PLs}-2+\mathrm{PLs})\end{array}$} & \multicolumn{2}{|c|}{$\begin{array}{c}\mathrm{K} 2 \\
(2 \mathrm{PLs}-4 \mathrm{PLs})\end{array}$} & \multicolumn{2}{|c|}{$\begin{array}{c}\mathrm{K} 2 \\
(2+\mathrm{PLs}-3 \mathrm{PLs})\end{array}$} & \multicolumn{2}{|c|}{$\begin{array}{c}\mathrm{K} 2 \\
(2+\mathrm{PLs}-4 \mathrm{PLs})\end{array}$} \\
\hline & & & & & & & & & & & & & & & & \\
\hline Turnover & 0.62 & & 0.64 & & 0.21 & & 0.95 & & 0.89 & & 0.79 & & 0.27 & & 0.52 & \\
\hline Op. Prof. & 0.50 & & 0.34 & & 0.85 & & 0.32 & & 0.84 & & 0. & & 0. & & 0.12 & \\
\hline Cash In Op. Act. & 0.79 & & 0.47 & & 0.61 & & 0.56 & & 0.52 & & 0.39 & & 0.99 & & $0.8 \mathrm{I}$ & \\
\hline ROCE & 0.56 & & 0.63 & & 0.34 & & 0.42 & & 0.69 & & 0.57 & & 0.18 & & 0.95 & \\
\hline \multicolumn{17}{|c|}{ Non-Economic/Financial Ind. } \\
\hline Employees & $\underline{0.00}$ & & $\underline{0.00 *}$ & & 0.11 & & 0.21 & & $0.00 *$ & & $0.00 *$ & & 0.42 & & 0.11 & \\
\hline Fixed Assets & 0.17 & $\underline{0.05}$ & $\overline{0.11}$ & 0.08 & 0.14 & 0.06 & 0.98 & 0.98 & $\overline{0.54}$ & 0.65 & $\overline{0.39}$ & 0.48 & 0.09 & $\underline{0.02}$ & 0.02 & $0.00 *$ \\
\hline Tangible Assets & 0.11 & $\overline{0.04}$ & $\underline{0.03}$ & $\underline{0.03}$ & 0.25 & 0.08 & 0.91 & 0.08 & 0.21 & 0.25 & $0.4 I$ & 0.38 & $\underline{0.03}$ & $\overline{0.01} *$ & $\overline{0.03}$ & $\underline{0.01} *$ \\
\hline Current Assets & 0.56 & $\overline{0.62}$ & 0.48 & $\overline{0.43}$ & 0.30 & 0.45 & 0.56 & 0.42 & 0.93 & 0.90 & 0.45 & 0.2 & $\overline{0.42}$ & 0.68 & $\overline{0.19}$ & $\overline{0.32}$ \\
\hline cock \& W.I.P. & 0.01 & 0.00 & 0.99 & 0.70 & 0.01 & $0.00 *$ & 0.03 & 0.02 & 0.92 & 0.73 & 0.04 & 0.06 & 0.02 & 0.02 & 0.99 & 0.60 \\
\hline Working Capital & 0.43 & 0.61 & 0.67 & 0.72 & 0.18 & 0.29 & 0.39 & $\overline{0.47}$ & 0.67 & 0.73 & 0.61 & 0.72 & 0.54 & 0.52 & 0.11 & 0.22 \\
\hline
\end{tabular}

NB the value in the cell is the $p$ value of the corresponding test. All the values less than or equal to 0.05 are underlined. For the Mann-Whitney tests, an * marks the entries for which the $p$ value is less than the adjusted alpha after the Benjamini-Hochberg correction.

Whitney tests have been used to analyse the differences between the financial statements indicators of the various PLs groups ${ }^{85}$ To control for size effects, each indicator has been divided by the firm's number of employees, or their turnover. Normalization via turnover has been indicated with shaded areas in the table.

Table 6 reports the results of the tests. The first column reports the results of the comparison for each indicator across the four PL groups. The other columns report the results of all the relevant pairwise comparisons for the groups at hand.

The Kruskal-Wallis tests show that the EF indicators did not change across the various PLs in the same sector (SIC code). Thus, both $H_{1 a}$ and $H_{1 b}$ failed to be rejected. Accordingly, no PLs group is more profitable $\left(H_{l a}\right)$, not even the ones focusing on knowledge-intensive service capabilities $\left(H_{1 b}\right)$. As for the NEF indicators, the differences in Number of Employees, Fixed and Tangible Assets and Stock \& W.I.P. did not reach statistical significance. PLs have different sizes in regards to Number of Employees and different amounts of Fixed and Tangible Assets (trucks, storage rooms, etc.) and Stock \& W.I.P. For these indicators, it is correct to assume that the different bundles of service capabilities offered by PLs gave rise to a different asset structure.

The pairwise Mann-Whitney tests complemented the Kruskal-Wallis results. Specifically, it is interesting to note that the $2+$ PLs group, i.e. the 2PLs offering a wide range of asset-intensive services, did not set themselves apart from the 2PLs. On the contrary, they were significantly different from the 3-4PLs. In light of these results, one might question whether the organizational risk and complexity needed to offer additional service capabilities was worth bearing in this case.

\section{Discussion}

An analysis of service capabilities in the freight transport by road industry (SIC 49410) was used to gain deeper insights 
into the study of PL's strategic behaviour. ${ }^{14,21,23,38,86}$ The empirical evidence demonstrates that PLs in the road transport are of four main types, namely 2 PLs, $2+$ PLs, 3PLs, and 4PLs. 2+PLs offer basic haulage services (2PLs) along with additional value-added services that exploit tangible resources. ${ }^{87}$ These PLs insource activities that extend the business scope of haulage companies such as truck repair and maintenance. ${ }^{20,24,88,89}$ These firms respond to an industry-wide need, e.g. truck maintenance, by developing the capabilities to carry out such activities. These PLs have reacted to the industry concentration process by horizontally integrating their resource-intensive services, rather than vertically integrating as 3-4PLs have done. In this way, 2+PLs are different from both 2PLs and 3-4PLs.

Regarding the relationship between PL groups and economic-financial (EF) indicators, the test of $H_{l a-b}$ demonstrated that firms with different combinations of service capabilities in the same business sector (SIC code 49410) do not show statistically significant differences in the Turnover, Operating Profits, Cash in from Operating Activities, ROCE, and the Credit Score. As for the hypothesis $\mathrm{H}_{2}$, namely the relationship between PL groups and non-economic/financial (NEF) indicators, it was rejected for the majority of the indicators and failed to be rejected for Number of Employees, Fixed and Tangible Assets, and Stock and W.I.P. The same pattern was observed when the 2PLs and 2+PLs were placed in the same group and contrasted with 3-4PLs.

The results supported other scholar's claims for specific groups of PLs, such as 3PLs. According to these results, there may not be a direct relationship between the offering of service capabilities and performance. ${ }^{39}$ These service capabilities may only have an indirect effect on certain performance indicators. ${ }^{31}$

The absence of a direct relationship between service capabilities and financial indicators may seem in contrast with some of the consequences of RBV theory. The market segment within the same industrial sector is the main reason for this outcome ${ }^{1}$. As discussed by Lai ${ }^{24}$ for 3 PLs and by Chao et al. ${ }^{90}$ for airline cargo transport, PLs in the road transport sector target their particular market niche and achieve the same levels of performance irrespective of the particular niche exploited within the same business (same SIC code). Thus, RBV applies to the market niche, not to the whole sector.

The results found by Hofmann and Lampe ${ }^{21}$ were also useful when discussing the present findings. Hofmann and Lampe $^{21}$ have shown that PLs with different SIC codes (e.g., sea-freight and parcel delivery) have equal profitability and different asset structure (namely different values in the indicators labelled in this study as NEF). The present study has demonstrated that the same relationship is valid for different PLs with the same SIC code (49410). This means that the asset structure among different PLs varies, although their 'business' in statistical terms - the SIC code - is the same. Therefore, in this case it is possible to conclude that the asset structure is a good predictor of PL's service scope. Furthermore, the results have extended studies on the strategic group analysis of PLs' that were undertaken by Lirn, Shang, and $\mathrm{Lu}^{38}$ and by Liu and Lyons. ${ }^{20}$ Differently from the latter studies, the focus of this research is on PLs with the same SIC code, and the use of financial statements data to draw inferences. The results have shown that PLs with the same SIC code are homogeneous in terms of performance. Because the SIC code is the same, the differences between the PLs' service capabilities can be attributed to different service strategies in the same business. Thus, the results have shown that key performance indicators in the same SIC code did not vary across various strategic groups. In other words, the market niches within the same SIC code have the same profitability.

\section{Implications and limitations}

An analysis of the relationship between service capability bundles and financial statements indicators is essential for management. ${ }^{28}$ This research has provided deeper insights into the 'black box' of resource and capability configuration through an empirical appraisal of capability bundling in road transport firms. ${ }^{1,28,49}$ This study confirms the existence of various strategic groups within a circumscribed industrial sector, as pointed out by RBV theory ${ }^{1,91}$ and as empirically derived by various scholars. ${ }^{23,38}$

This analysis is appealing because the SIC classification, as well as other similar ones (e.g., NACE rev. 2), are used by governments, institutions, and trade associations to collect statistics on industries. Knowing the stratification within a particular SIC code adds a layer to those statistics and can be a useful approach to get more insights on specific sectors. In addition, the results have shown that economic-financial indicators are constant for this particular SIC code. Turnover, Operating Profits, Cash-in from Operating Activities, and ROCE did not show statistically significant variations for a sample of companies in the 49410 SIC code. Thus, managers can use these indicators as a benchmark to their firm's performance. This is useful because financial data grouped by the SIC code are easily available, enabling managers to use this data as lagging indicators for their strategic decisions. Further research might investigate whether this pattern is common for other SIC codes that are relevant to PLs.

Finally, this research has developed a heuristic approach to identify and classify service capabilities starting from open secondary data, which can be replicated in other business sectors. ${ }^{11}$ This heuristic study supports managers in identifying capabilities both in their firms and in their competitors. ${ }^{23,38,92,93}$ This ability is fundamental for managers who must set strategies in a rapidly changing environment. ${ }^{22,94-97}$

This study has limitations too, which can also be regarded as opportunities for future research. Firstly, the 
study is based on a single country. On the one hand, this is an advantage for a ceteris paribus analysis. On the other hand, it may fail to account for idiosyncratic factors of the chosen country. Future research can be devoted to investigating whether the results in this paper apply elsewhere. Secondly, the study is cross-sectional. The effects, which were found to be statistically non-significant in a 1-year period, might become significant over a longer time span. That is, companies that have specific capabilities might show a competitive advantage over a longer time span. Thirdly, the study infers the presence of certain service capabilities by analysing the firms' websites; it does not verify their possession and exploitation. Other methodologies, such as case studies, are required to investigate issues related to the possession and exploitation of service capabilities, thus extending the results of the present analysis. Using a different scale (e.g., a 0-5 scale) would serve the same purpose and represents another route for future research. ${ }^{98}$

\section{Data availability statement}

The firms' capabilities have been derived from public domain resources (firms' websites). The financial statements data are available in anonymized form from the corresponding author, L.T., upon reasonable request.

\section{Declaration of conflicting interests}

The author(s) declared no potential conflicts of interest with respect to the research, authorship, and/or publication of this article.

\section{Funding}

The author(s) received no financial support for the research, authorship, and/or publication of this article.

\section{ORCID iD}

Armando Calabrese (D) https://orcid.org/0000-0002-4035-5717

\section{References}

1. Sirmon DG, Hitt MA and Ireland DR. Managing firm resources in dynamic environments to create value: looking inside the black box. Acad Manage Review 2007; 32(1): 273-292.

2. Barney JB and Clark DN. Resource-based theory: creating and sustaining competitive advantage. Oxford: Oxford University Press, 2007.

3. Priem RL and Butler JE. Tautology in the resource-based view and the implications of externally determined resource value: further comments. Acad Manage Review 2001; 26(1): 57-66.

4. Valtanen I. Service transition strategies in service-dominant settings: towards all finance solutions in SME markets. J Finan Serv Market 2014; 19(1): 52-70.

5. Ostrom AL, Parasuraman A, Bowen DE, et al. Service research priorities in a rapidly changing context. $J$ Serv Res 2015; 18(2): 127-159.
6. Den Hertog P, Van Der Aa W and De Jong MW. Capabilities for managing service innovation: towards a conceptual framework. J Serv Manage 2010; 21(4): 490-514.

7. Droege H, Hildebrand D and Heras Forcada MA. Innovation in services: present findings, and future pathways. J Serv Manage 2009; 20(2): 131-155.

8. Khaksar SMS, Chu MT, Rozario S, et al. Knowledge-based dynamic capabilities and knowledge worker productivity in professional service firms the moderating role of organisational culture. Knowl Manage Res Pract 2020; 25: 1-8.

9. He P, Niu H, Sun Z, et al. Accounting index of COVID-19 impact on Chinese industries: a case study using big data portrait analysis. Emerg Mark Finance Trade 2020; 56(10): 2332-2349.

10. Bigdeli AZ, Bustinza OF, Vendrell-Herrero F, et al. Network positioning and risk perception in servitization: evidence from the UK road transport industry. Int J Prod Res 2017; 56(6): 2169-2183.

11. Karia $\mathrm{N}$ and Wong CY. The impact of logistics resources on the performance of Malaysian logistics service providers. Prod Plan Control 2013; 24(7): 589-606.

12. Ellinger AE, Ketchen DJ, Hult GTM, et al. Market orientation, employee development practices, and performance in logistics service provider firms. Ind Mark Manage 2008; 37(4): 353-366.

13. Oberhofer P and Fürst E. Sustainable development in the transport sector: influencing environmental behaviour and performance. Bus Strategy Environ 2013; 22(6): 374-389.

14. Sornn-Friese H. Interfirm linkages and the structure and evolution of the Danish trucking industry. Transp J 2005; 44(4): 10-26.

15. García-Arca J, Prado-Prado JC and Fernández-González AJ. Integrating KPIs for improving efficiency in road transport. Int J Phys Distrib Logis Manage 2018; 48(9): 931-951.

16. Sternberg $\mathrm{H}$ and Harispuru L. Identifying root causes of inefficiencies in road haulage: case studies from Sweden, Switzerland and Germany. Int J Logist Res Appl 2017; 20(1): 73-83.

17. Villarreal B, Garza-Reyes JA, Kumar V, et al. Improving road transport operations through lean thinking: a case study. Int J Logist Res Appl 2017; 20(2): 163-180.

18. Garza-Reyes JA, Villarreal B, Kumar V, et al. Lean and green in the transport and logistics sector - a case study of simultaneous deployment. Prod Plan Control 2016; 27(15): 1221-1232.

19. Villarreal B, Garza-Reyes JA and Kumar V. Lean road transportation - a systematic method for the improvement of road transport operations. Prod Plan Control 2016; 27(11): 865-877.

20. Liu C-L and Lyons AC. An analysis of third-party logistics performance and service provision. Transp Res Part E: Logist Transp Review 2011; 47(4): 547-570.

21. Hofmann E and Lampe K. Financial statement analysis of logistics service providers: ways of enhancing performance. Int J Logist Res Appl 2013; 43(4): 321-342. 
22. Liu C-L and Lai P-Y. Impact of external integration capabilities of third-party logistics providers on their financial performance. Int J Logist Manage 2016; 27(2): 263-283.

23. Wong CY and Karia N. Explaining the competitive advantage of logistics service providers: a resource-based view approach. Int J Prod Econo 2010; 128(1): 51-67.

24. Lai K. Service capability and performance of logistics service providers. Transp Res Part E: Logist Transp Review 2004; 40(5): 385-399.

25. Barney J. Firm resources and sustained competitive advantage. J Manage 1991; 17(1): 99-120.

26. Wernerfelt B. A resource-based view of the firm. Strat Manage $J$ 1984; 5(2): 171-180.

27. Helfat CE and Peteraf MA. The dynamic resource-based view: capability lifecycles. Strat Manage J 2003; 24(10): 997-1010.

28. Karia N, Wong CY, Asaari MHAH, et al. The effects of resource bundling on third-party logistics providers' performance. Int J Eng Bus Manage 2015; 7: 7-9.

29. Liu X, Grant DB, McKinnon AC, et al. An empirical examination of the contribution of capabilities to the competitiveness of logistics service providers. Int J Phys Distrib Logist Manage 2010; 40(10): 847-866.

30. Day GS. The capabilities of market-driven organizations. J Mark 1994; 58(4):37-52.

31. Kuo S-Y, Lin P-C and Lu C-S. The effects of dynamic capabilities, service capabilities, competitive advantage, and organizational performance in container shipping. Trans Res Part A: Policy Prac 2017; 95: 356-371.

32. Evangelista P, Mogre R, Perego A, et al. A survey based analysis of IT adoption and 3PLs' performance. Supply Chain Manage Int J 2012; 17(2): 172-186.

33. Zacharia ZG, Sanders NR and Nix NW. The emerging role of the third-party logistics provider (3PL) as an orchestrator. $J$ Bus Logist 2011; 32(1): 40-54.

34. Jiang J, Jin Y and Dong CY. Research on the e-business logistics service mode based on branch storage and warehouse financing. Int J Serv Technol Manage 2016; 22(3): 203-217.

35. Zuo Y. Making smart manufacturing smarter - a survey on blockchain technology in Industry 4.0. Enterprise Inf Syst 2021; 16: 1-31.

36. Fang $\mathrm{X}$ and Chen HC. Using vendor management inventory system for goods inventory management in IoT manufacturing. Enterprise Inf Syst 2021; 27: 1-27.

37. Hofmann E. Inventory financing in supply chains. Int $J$ Phys Distrib Logist Manage 2009; 39(9): 716-740.

38. Lirn TC, Shang KC and Lu CS. Strategic groups evaluation and firm performance for logistics services providers. Int $J$ Ship Trans Logist 2014; 6(6): 652-679.

39. Lai F, Zhao X and Wang Q. Taxonomy of information technology strategy and its impact on the performance of thirdparty logistics (3PL) in china. Int J Prod Res 2007; 45(10): 2195-2218.

40. Panayides PM. The impact of organizational learning on relationship orientation, logistics service effectiveness and performance. Ind Mark Manage 2007; 36(1): 68-80.
41. Richey RG, Daugherty PJ and Roath AS. Firm technological readiness and complementarity: capabilities impacting logistics service competency and performance. J Bus Logist 2007; 28(1): 195-228.

42. Shang K-C. Integration and organisational learning capabilities in third-party logistics providers. Serv Ind J 2009; 29(3): 331-343.

43. Huang S-M, Ou C-S, Chen C-M, et al. An empirical study of relationship between IT investment and firm performance: a resource-based perspective. Euro J Operat Res 2006; 173(3): 984-999.

44. Ellinger AE, Lynch DF and Hansen JD. Firm size, web site content, and financial performance in the transportation industry. Ind Mark Manage 2003; 32: 177-185.

45. Barney JB and Arikan AM. The resource-based view: origins and implications. In: Hitt MA, Freeman RE and Harrison JS (eds) The Blackwell handbook of strategic management. Hoboken, NJ: Wiley Blackwell, 2001.

46. Liebeskind JP. Knowledge, strategy, and the theory of the firm. Strat Manage J 1996; 17(52): 93-107.

47. Fleiss JL, Levin B and Paik MC. Statistical methods for rates and proportions. Hoboken, NJ: John Wiley Sons, 2013.

48. Selviaridis K and Spring M. Third party logistics: a literature review and research agenda. Int J Logist Manage 2007; 18(1): 125-150.

49. Sirmon DG and Hitt MA. Managing resources: linking unique resources, management, and wealth creation in family firms. Entreprene Theory Prac 2003; 27(4): 339-358.

50. Rumelt RP. How much does industry matter? Strat Manage $J$ 1991; 12(3): 167-185.

51. Dawes J. The relationship between subjective and objective company performance measures in market orientation research: further empirical evidence. Mark Bull 1999; 10: 65-75.

52. Covin JG, Slevin DP and Schultz RL. Implementing strategic missions: effective strategic, structural and tactical choices. J Manage Stud 1994; 31(4): 481-506.

53. Krippendorff K.Content analysis: an introduction to its methodology. Thousand Oaks, CA: Sage, 2004.

54. Gaiardelli P, Resta B, Martinez V, et al. A classification model for product-service offerings. J Clean Prod 2014; 66(1): 507-519.

55. Wong CY, Grant DB and Allan B. Logistics and supply chain education and jobs: a study of UK markets. Int J Logist Manage 2014; 25(3): 537-552.

56. Wooldridge JM.Introductory econometrics: a modern approach. Toronto: Nelson Education, 2015.

57. Friedman J, Hastie T and Tibshirani R. The elements of statistical learning. Berlin: Springer, 2001.

58. Arvis J-F, Saslavsky D, Ojala L, et al. Connecting to compete: trade logistics in the global economy. The logistics performance index and its indicators. Washington, DC: World Bank, 2016.

59. Arvis J-F, Saslavsky D, Ojala L, et al. Connecting to compete: trade logistics in the global economy. The logistics 
performance index and its indicators. Washington, DC: World Bank, 2014.

60. Arvis J-F, Saslavsky D, Ojala L, et al. Connecting to compete: trade logistics in the global economy. The logistics performance index and its indicators. Washington, DC: World Bank, 2018.

61. Arvis J-F, Saslavsky D, Ojala L, et al. Connecting to compete: trade logistics in the global economy. The logistics performance index and its indicators. Washington, DC: World Bank, 2010.

62. Arvis J-F, Saslavsky D, Ojala L, et al. Connecting to compete: trade logistics in the global economy. The logistics performance index and its indicators. Washington, DC: World Bank, 2007.

63. Dubois A and Gadde L-E. Systematic combining: an abductive approach to case research. J Bus Res 2002; 55(7): 553-560.

64. Shankar A and Datta B. Measuring e-service quality: a review of literature. Int J Serv Technol Manage 2020; 26(1): 77-100.

65. Stefansson G. Collaborative logistics management and the role of third-party service providers. Int J Phys Distri Logist Manage 2006; 36(2): 76-92.

66. Gunasekaran A and Ngai EWT. The successful management of a small logistics company. Int J Phys Distri Logist Manage 2003; 33(9): 825-842.

67. Larson PD and Gammelgaard B. Logistics in Denmark: a survey of the industry. Int J Logist 2001; 4(2): 191-206.

68. Van Hoek RI. The contribution of performance measurement to the expansion of third party logistics alliances in the supply chain. Int J Operat Prod Manage 2001; 21(1/2): 15-29.

69. Van Hoek RI. The role of third-party logistics providers in mass customization. Int J Logist Manage 2000; 11(1): 37-46.

70. Van Hoek RI. The purchasing and control of supplementary third-party logistics services. J Supply Chain Manage 2000; 36(4): 14-26.

71. Murphy PR and Poist RF. Third-party logistics: some user versus provider perspectives. J Bus Logist 2000; 21(1): 121-133.

72. Lieb RC and Randall HL. 1997 CEO perspectives on the current status and future prospects of the third party logistics industry in the United States. Transp J 1999; 38(3): 28-41.

73. Lieb RC and Randall HL. CEO perspectives on the current status and future prospects of the third-party logistics industry in the United States. Transp Logist 1996; 1(1): 51-66.

74. La Londe BJ and Masters JM. Emerging logistics strategies: blueprints for the next century. Int J Phys Distri Logist Manage 1994; 24(7): 35-47.

75. Cassell $\mathrm{CE}$ and Symon GE. Essential guide to qualitative methods in organizational research. Thousand Oaks, CA: Sage, 2004.

76. Bryman A. Social research methods. Oxford: Oxford university press, 2015.

77. Creswell JW and Miller DL. Determining validity in qualitative inquiry. Theory into Prac 2000; 39(3): 124-130.

78. Wildemuth BM. Applications of social research methods to questions in information and library science. Westport, CT: Greenwood Press, 2009.
79. Kassarjian HH. Content analysis in consumer research. J Con Res 1977; 4(1): 8-18.

80. Lu C-S and Yang C-C. Logistics service capabilities and firm performance of international distribution center operators. Serv Ind J 2010; 30(2): 281-298.

81. Van der Veeken DJM and Rutten WGMM. Logistics service management: opportunities for differentiation. Int $J$ Logist Manage 1998; 9(2): 91-98.

82. Huefner RJ and Gupta MC. A cluster analysis study of financial ratios and industry characteristics. J Account Res 1972; 10(1): 77-95.

83. Gupta MC. The effect of size, growth and industry on the financial structure of manufacturing companies. $J$ Finance 1969; 24(3): 517-529.

84. Martikainen T, Perttunen J and Yli-Olli P. Financial ratio distribution irregularities: implications for ratio classification. Euro J Operat Res 1995; 80(1): 34-44.

85. Hollander M, Wolfe DA and Chicken E. Nonparametric statistical methods. Hoboken, NJ: John Wiley \& Sons, 2015.

86. Yang X. Status of third party logistics - a comprehensive review. J Logist Manage 2014; 3(1): 17-20.

87. Amit R and Schoemaker PJH. Strategic assets and organizational rent. Strat Manage J 1993; 14(1): 33-46.

88. He N, Jiang ZZ, Wang J, et al. Maintenance optimisation and coordination with fairness concerns for the service-oriented manufacturing supply chain. Enter Inf Syst 2020; 23: 1-31.

89. Traore BB, Kamsu Foguem B, Tangara F, et al. Serviceoriented computing for intelligent train maintenance. Enter Inf Syst 2021; 13(1): 63-86.

90. Chao CC, Lirn TC and Shang KC. Market segmentation of airline cargo transport. Serv Ind J 2013; 33(15-16): 1672-1685.

91. Peteraf MA. The cornerstones of competitive advantage: a resource-based view. Strat Manage J 1993; 14(3): 179-191.

92. Porter ME. Competitive strategy: techniques for analyzing industries and competitors. New York, NY: Simon and Schuster, 2008.

93. Bisp S, Sørensen E and Grunert KG. Using the key success factor concept in competitor intelligence and benchmarking. Comp Intel Rev 1998; 9(3): 55-67.

94. Shang K-C and Marlow PB. Logistics capability and performance in Taiwan's major manufacturing firms. Transp Res Part E: Logist Transp Rev 2005; 41(3): 217-234.

95. Sinkovics RR and Roath AS. Strategic orientation, capabilities, and performance in manufacturer - 3PL relationships. J Bus Logist 2004; 25(2): 43-64.

96. Capece G, Cricelli L, Di Pillo F, et al. The Italian gas retail market: a cluster analysis based on performance indexes. WIT Trans Eco Environ 2009; 121: 1743-3541.

97. Capece G, Di Pillo F and Levialdi N. Measuring and comparing the performances of energy retail companies: firm strategies following the liberalization. Int J Energy Sector Manage 2013; 7(4): 491-515.

98. D'Adamo I, Gastaldi M and Rosa P. Recycling of end-of-life vehicles: assessing trends and performances in Europe. Techno Forecast Soc Change. 2020; 152: 119887. 
99. Gravetter FJ and Wallnau LB. Essentials of statistics for the behavioral sciences. Wadsworth, $\mathrm{OH}$ : Cengage Learning, 2014.
100. David A, Dennis S, Williams T, et al. Statistics for business \& economics. Wadsworth, $\mathrm{OH}$ : Cengage Learning, 2013.

\section{Appendix I}

Legend of the acronyms corresponding to the services offered. In each service capability type $\left(T_{i}\right)$, the services are enumerated $\left(\mathrm{T}_{\mathrm{ij}}\right)$.

$\mathbf{T}_{11}$ : Basic Warehousing Services;

$\mathbf{T}_{\mathbf{1 2}}$ : Tracking Services;

$\mathbf{T}_{13}$ : Specialized Transport Services;

$T_{14}$ : Contract Solutions;

$\mathbf{T}_{21}$ : Diagnostic Services;

$\mathbf{T}_{\mathbf{2 2}}$ : Workshop Facilities;
$\mathbf{T}_{\mathbf{2 3}}$ : Additional Equipment and Facility Services;

$\mathbf{T}_{24}$ : Environmental Services;

$\mathbf{T}_{31}$ : Advanced Training Academies;

$\mathbf{T}_{32}$ : Advanced Warehousing Services;

$\mathbf{T}_{33}$ : Advanced Telematics Solutions;

$\mathbf{T}_{34}$ : Consulting Services.

Table IA. Service capabilities of the PLs in the sample.

\begin{tabular}{|c|c|c|c|c|c|c|c|c|c|c|c|c|c|}
\hline Name & SIC & TII & $\mathrm{T} 12$ & TI3 & $\mathrm{TI} 4$ & $\mathrm{~T} 2 \mathrm{I}$ & $\mathrm{T} 22$ & $\mathrm{~T} 23$ & $\mathrm{~T} 24$ & T31 & T32 & T33 & T34 \\
\hline A.J. Maiden And Son Limited & 49410 & $x$ & $x$ & $x$ & $x$ & & & $x$ & & & & & \\
\hline Abbey Logistics Group Limited & 49410 & $x$ & $x$ & $x$ & & & & $x$ & $x$ & & $x$ & & \\
\hline Andyfreight Holdings Limited & 49410 & $x$ & $x$ & $x$ & & & & & $x$ & & $x$ & $x$ & $x$ \\
\hline Boughey Distribution Limited & 49410 & $x$ & $x$ & & $x$ & & & & & & $x$ & $x$ & $x$ \\
\hline Browns Distribution Services Limited & 49410 & $x$ & $x$ & $x$ & & & & & & & $x$ & $x$ & \\
\hline C. Butt Limited & 49410 & $x$ & $x$ & & & $x$ & & $x$ & & & $x$ & & $x$ \\
\hline C. S. Ellis (Holdings) Limited & 49410 & $x$ & $x$ & $x$ & & $x$ & $x$ & & $x$ & & $x$ & $x$ & $x$ \\
\hline C.M. Downton (Haulage Contractors) Limited & 49410 & $x$ & $x$ & $x$ & & $x$ & $x$ & & $x$ & & $x$ & $x$ & $x$ \\
\hline Canute Haulage Group Limited (No Medical Subsidiary) & 49410 & $x$ & $x$ & $x$ & & & & $x$ & & & $x$ & $x$ & $x$ \\
\hline Chambers And Cook (European Services) Limited & 49410 & $x$ & $x$ & $x$ & $x$ & & & $x$ & & & & $x$ & \\
\hline Clipper Logistics PLC & 49410 & $x$ & $x$ & $x$ & $x$ & & & & $x$ & & $x$ & $x$ & $x$ \\
\hline D. \& P. Haulage Limited & 49410 & $x$ & $x$ & $x$ & & & & & & & & & \\
\hline D. R. Macleod Limited & 49410 & $x$ & & $x$ & & & & & & & & & \\
\hline David Bratt \& Sons (Haulage) Limited & 49410 & $\mathrm{x}$ & & $x$ & & $x$ & & $x$ & & $x$ & & & \\
\hline David Hathaway Holdings Limited & 49410 & $x$ & $x$ & & & & & $x$ & & & $x$ & $x$ & \\
\hline David Watson Transport Limited & 49410 & $x$ & $x$ & $x$ & & $x$ & & & & $x$ & & & $x$ \\
\hline Delamode Plc & 49410 & $x$ & $x$ & $x$ & & & & & & & $x$ & $x$ & $x$ \\
\hline DSV Road Limited & 49410 & $x$ & $x$ & $x$ & & & & & & & $x$ & $x$ & $x$ \\
\hline Eddie Stobart Limited & 49410 & $x$ & $x$ & $x$ & $x$ & $x$ & & & & & $x$ & $x$ & $x$ \\
\hline Expect Distribution Limited & 49410 & $x$ & $x$ & & & $x$ & & & & & & $x$ & \\
\hline Ferguson Freight Holdings Limited & 49410 & $x$ & $x$ & $x$ & & $x$ & $x$ & $x$ & & $x$ & & & \\
\hline Fergytrux Limited & 49410 & $x$ & $x$ & $x$ & & & & $x$ & $x$ & & & $x$ & $x$ \\
\hline FTS Hatswell Limited & 49410 & $x$ & $x$ & $x$ & & $x$ & & & & $x$ & & & \\
\hline George Allinson (Transport) Limited & 49410 & $x$ & $x$ & $x$ & $x$ & & & & & & $x$ & $x$ & $x$ \\
\hline Goldstar (Felixstowe) Limited & 49410 & $x$ & & $x$ & & $x$ & & $x$ & & $x$ & & & \\
\hline Gregory Distribution (Holdings) Limited & 49410 & $x$ & $x$ & $x$ & & $x$ & $x$ & & $x$ & $x$ & & & \\
\hline Gwynedd Transport Limited & 49410 & $x$ & $x$ & $x$ & & & & & & & & & \\
\hline H. \& M. Ventures Limited & 49410 & $x$ & $x$ & $x$ & & & & & & & & & \\
\hline H. E. Payne Transport Limited & 49410 & $x$ & & $x$ & & & & & & & & & \\
\hline Harris Transport Limited & 49410 & $x$ & $x$ & $x$ & $x$ & & & & & & & & \\
\hline Haulage Shetland Limited & 49410 & $x$ & & $x$ & & & & & & & & & \\
\hline Hicks Logistics Ltd & 49410 & $x$ & $x$ & $x$ & & & & & & & & & \\
\hline I. J. Mcgill Transport Limited & 49410 & $x$ & $x$ & $x$ & $x$ & & & $x$ & & & $x$ & $x$ & $x$ \\
\hline J. Hayward \& Sons of Walsall Limited & 49410 & $x$ & $x$ & $x$ & & $x$ & & $x$ & & & & $x$ & \\
\hline J. R. Adams (Newcastle) Limited & 49410 & $x$ & & $x$ & & $x$ & $x$ & $x$ & & & & & \\
\hline Jack Richards Holdings Limited & 49410 & $x$ & $x$ & $x$ & $x$ & $x$ & $x$ & $x$ & & & & & \\
\hline James Kemball Limited & 49410 & $x$ & $x$ & $x$ & $x$ & $x$ & & $x$ & & & & $x$ & $x$ \\
\hline Jempson Holdings Limited & 49410 & $x$ & & $x$ & & & $x$ & $x$ & & $x$ & & & \\
\hline John Hackling (Transport) Limited & 49410 & $x$ & $x$ & $x$ & & $x$ & & & & $x$ & $x$ & $x$ & $x$ \\
\hline John Truswell \& Sons (Garage) Limited & 49410 & $x$ & $x$ & $x$ & $x$ & $x$ & $x$ & $x$ & & $x$ & & & \\
\hline K. Investments Limited & 49410 & $x$ & $x$ & $x$ & $x$ & $x$ & & $x$ & & & & & $x$ \\
\hline KBC Logistics Limited & 49410 & $x$ & $x$ & $x$ & & $x$ & & & & & & & \\
\hline Kenyon Road Haulage Limited & 49410 & $x$ & $x$ & $x$ & $x$ & & & & & & & & \\
\hline
\end{tabular}


Table IA. (continued)

\begin{tabular}{|c|c|c|c|c|c|c|c|c|c|c|c|c|c|}
\hline Name & SIC & TII & TI2 & TI3 & TI4 & T2I & $\mathrm{T} 22$ & T23 & T24 & T3। & T32 & T33 & T34 \\
\hline Knights of Old Group Limited & 49410 & $\mathrm{x}$ & $\mathrm{x}$ & $\mathrm{x}$ & $\mathrm{x}$ & $x$ & & & & $\mathrm{x}$ & $\mathrm{x}$ & & $x$ \\
\hline Lenham Storage Company Limited & 49410 & $x$ & $x$ & $x$ & $x$ & & & $x$ & & & & & \\
\hline Linkchoice Limited & 49410 & $x$ & $x$ & $x$ & & & & & & & & & \\
\hline Logistic Planning Services Limited & 49410 & $x$ & & $x$ & $x$ & & & & & & & & \\
\hline Massey Wilcox Transport Limited & 49410 & $\mathrm{x}$ & $\mathrm{x}$ & $\mathrm{x}$ & $\mathrm{x}$ & & & $\mathrm{x}$ & & & & & \\
\hline Maxi Caledonian Limited & 49410 & $x$ & $\mathrm{x}$ & $x$ & & & & $x$ & $\mathrm{x}$ & & & $\mathrm{x}$ & $x$ \\
\hline Meachers Group Investments Limited & 49410 & $\mathrm{x}$ & $\mathrm{x}$ & $\mathrm{x}$ & & & & & & $\mathrm{x}$ & $\mathrm{x}$ & $\mathrm{x}$ & $x$ \\
\hline Mini Clipper Limited & 49410 & $x$ & $x$ & $x$ & & & & & $x$ & & $x$ & & $x$ \\
\hline Newell And Wright Holdings Limited & 49410 & $x$ & $x$ & $x$ & $\mathrm{x}$ & $\mathrm{x}$ & $x$ & $x$ & & & $x$ & $x$ & $x$ \\
\hline Nidd Transport Limited & 49410 & $x$ & $x$ & $x$ & & & & & & & & & \\
\hline Northwards Ltd & 49410 & $x$ & $\mathrm{x}$ & $\mathrm{x}$ & & & & & & & & & \\
\hline Owens (Road Services) Limited & 49410 & $x$ & $\mathrm{x}$ & $x$ & & $\mathrm{x}$ & $x$ & $x$ & & & $x$ & & \\
\hline P. \& H. Contract Services Limited & 49410 & $x$ & $x$ & $x$ & $\mathrm{x}$ & & & & & & $x$ & $x$ & $\mathrm{x}$ \\
\hline P. D. Bannister Haulage Limited & 49410 & $\mathrm{x}$ & & $x$ & $\mathrm{x}$ & & & & & & & & \\
\hline Pegasus Express Limited & 49410 & $\mathrm{x}$ & $\mathrm{x}$ & $\mathrm{x}$ & & & & & & & $x$ & & \\
\hline Pennboro Limited & 49410 & $\mathrm{x}$ & $\mathrm{x}$ & $x$ & $\mathrm{x}$ & & & & & & $\mathrm{x}$ & $\mathrm{x}$ & $x$ \\
\hline PF Whitehead Transport Services Limited & 49410 & $x$ & $\mathrm{x}$ & & $\mathrm{x}$ & & & $\mathrm{x}$ & & & $\mathrm{x}$ & & $\mathrm{x}$ \\
\hline Price Express Transport Limited & 49410 & $\mathrm{x}$ & $\mathrm{x}$ & $\mathrm{x}$ & & & & & $\mathrm{x}$ & & & & \\
\hline R. Swain \& Sons Limited & 49410 & $x$ & $x$ & $x$ & $x$ & $x$ & $x$ & $x$ & & & & $\mathrm{x}$ & $x$ \\
\hline Rase Distribution Ltd & 49410 & $x$ & $x$ & $x$ & $\mathrm{x}$ & & & & & & & $\mathrm{x}$ & \\
\hline Richard Read Holdings Limited & 49410 & $\mathrm{x}$ & & $x$ & & $\mathrm{x}$ & $x$ & $x$ & & & & & \\
\hline S. W. Group Logistics Limited & 49410 & $x$ & $\mathrm{x}$ & $x$ & $x$ & & & & & & $x$ & $\mathrm{x}$ & $x$ \\
\hline Shepherd Distribution Services Limited & 49410 & $x$ & & $x$ & & & & & & & & & \\
\hline Simpsons Logistics Limited & 49410 & $x$ & $x$ & $x$ & & & & & & & & & \\
\hline Tapfreight Limited & 49410 & $x$ & $x$ & $x$ & & & & & & & & $x$ & \\
\hline Thomas Maxwell \& Sons Limited & 49410 & $x$ & & $x$ & & $x$ & $x$ & & & & & & \\
\hline Tooles Transport Limited & 49410 & $x$ & $x$ & $x$ & & & & & & & & & \\
\hline Treasure Transport Services Ltd & 49410 & $x$ & $x$ & $x$ & & & & & & & & & \\
\hline Viamaster Transport Limited & 49410 & $x$ & $x$ & $x$ & $x$ & $x$ & & & & $x$ & & & \\
\hline W.A. Rainbow \& Sons Limited & 49410 & $x$ & $x$ & $x$ & & $x$ & $x$ & & & & & & \\
\hline W.H. Barley (Transport And Storage) Limited & 49410 & $x$ & $\mathrm{x}$ & $x$ & & & & & & & & $\mathrm{x}$ & \\
\hline William West \& Sons (Ilkeston) Limited & 49410 & $x$ & $x$ & $x$ & $\mathrm{x}$ & & & $x$ & & & & & \\
\hline Wincanton PLC & 49410 & $\mathrm{x}$ & $\mathrm{x}$ & $\mathrm{x}$ & $\mathrm{x}$ & $\mathrm{x}$ & $\mathrm{x}$ & $\mathrm{x}$ & $\mathrm{x}$ & $\mathrm{x}$ & $\mathrm{x}$ & & $\mathrm{x}$ \\
\hline
\end{tabular}

\section{Appendix 2}

Table 2A reports the group-wise (2PLs, 2+PLs, 3PLs, and 4PLs) first four moments for each indicator under exam. Skewness and kurtosis between \pm 2 show that the normality approximation is acceptable. ${ }^{99}$ In general, it can be observed that the distribution of each indicator departs from normal.

Table 2A. Moments of the indicators.

\begin{tabular}{|c|c|c|c|c|c|c|}
\hline & & Mean & Median & Std. Dev. & Skew. & Kurt. \\
\hline \multirow[t]{6}{*}{ Turnover } & 2PLs & 114504 & 102382 & 50516 & 3.05 & 12.05 \\
\hline & $2+\mathrm{PLs}$ & 100329 & 96799 & 33951 & 1.74 & 3.12 \\
\hline & $2-2+\mathrm{PLs}$ & 109980 & 97398 & 45991 & 3.00 & 12.48 \\
\hline & 3PLs & 111155 & 98228 & 41044 & 1.68 & 3.28 \\
\hline & 4PLs & 112158 & 100283 & 45078 & 1.56 & 2.79 \\
\hline & 3-4PLs & III466 & 99768 & 41520 & 1.54 & 2.33 \\
\hline \multirow[t]{6}{*}{ Op. Prof. } & 2PLs & 6014 & 5389 & 4862 & 0.75 & 0.81 \\
\hline & $2+\mathrm{PLs}$ & 5279 & 4650 & 2663 & 0.44 & 1.12 \\
\hline & $2-2+P L s$ & 5779 & 5316 & 4266 & 0.86 & 0.77 \\
\hline & 3PLs & 6109 & 4465 & 5512 & 1.25 & 0.99 \\
\hline & 4PLs & 3008 & 4315 & 2875 & 1.65 & 1.40 \\
\hline & 3-4PLs & 5146 & $43 \mid 4$ & 5010 & 1.37 & 2.35 \\
\hline \multirow[t]{6}{*}{ Cash In Op. Act. } & 2PLs & 21119 & 7687 & 35477 & 2.92 & 9.09 \\
\hline & $2+\mathrm{PLs}$ & -3907 & 6411 & 57506 & 3.67 & 13.90 \\
\hline & $2-2+\mathrm{PLs}$ & 13390 & 7483 & 44551 & 1.57 & 15.82 \\
\hline & 3PLs & 11101 & 7875 & 11738 & 1.33 & 1.77 \\
\hline & 4PLs & $1027 \mid$ & 7622 & 14499 & 2.32 & 5.93 \\
\hline & 3-4PLs & 10843 & 7621 & 12397 & 1.61 & 2.40 \\
\hline
\end{tabular}


Table 2A. (continued)

\begin{tabular}{|c|c|c|c|c|c|c|c|c|c|c|c|}
\hline \multirow{2}{*}{$\overline{R O C E}$} & & \multicolumn{2}{|c|}{ Mean } & \multicolumn{2}{|c|}{ Median } & \multicolumn{2}{|c|}{ Std. Dev. } & \multicolumn{2}{|c|}{ Skew. } & \multicolumn{2}{|c|}{ Kurt. } \\
\hline & 2PLs & 14 & & 14 & & 16 & & 0.26 & & 5.47 & \\
\hline & $2+\mathrm{PLs}$ & II & & 9 & & 6 & & 0.35 & & 1.32 & \\
\hline & $2-2+P L s$ & 13 & & 13 & & 14 & & 0.11 & & 7.40 & \\
\hline & 3PLs & 16 & & 13 & & II & & 0.57 & & 0.57 & \\
\hline & 4PLs & 62 & & 8 & & 160 & & 2.98 & & 8.92 & \\
\hline & 3-4PLs & 30 & & 13 & & 88 & & 5.26 & & 28.06 & \\
\hline \multirow[t]{6}{*}{ n. Employees } & 2PLs & 111 & & 95 & & 68 & & 3.64 & & 15.86 & \\
\hline & $2+\mathrm{PLs}$ & 319 & & 119 & & 446 & & 2.80 & & 8.87 & \\
\hline & $2-2+P L s$ & 177 & & 100 & & 270 & & 4.86 & & 27.31 & \\
\hline & 3PLs & 581 & & 165 & & 1003 & & 3.60 & & 6.17 & \\
\hline & 4PLs & 2237 & & 346 & & 5571 & & 2.98 & & 8.92 & \\
\hline & 3-4PLs & 1095 & & 168 & & 3187 & & 4.84 & & 24.62 & \\
\hline \multirow{6}{*}{ Fixed Assets } & 2PLs & 36011 & 0.33 & 27044 & 0.26 & 26479 & 0.24 & 1.29 & 0.96 & 1.98 & 0.48 \\
\hline & $2+\mathrm{PLs}$ & 42651 & 0.44 & 40076 & 0.41 & 16530 & 0.19 & 0.22 & 0.72 & 0.85 & 0.43 \\
\hline & 2-2PLs & 38130 & 0.37 & $3774 \mid$ & 0.34 & 23779 & 0.23 & I.0I & 0.71 & 1.70 & 0.09 \\
\hline & 3PLs & 33910 & 0.32 & 21822 & 0.22 & 30743 & 0.31 & 1.38 & 1.66 & 1.64 & 2.41 \\
\hline & 4PLs & 25766 & 0.23 & 25092 & 0.21 & 13583 & 0.11 & 0.56 & 1.29 & 0.87 & 2.01 \\
\hline & 3-4PLs & 31382 & 0.29 & 24589 & 0.21 & 26622 & 0.27 & 1.63 & 2.04 & 3.02 & 4.42 \\
\hline \multirow{6}{*}{ Tangible Assets } & 2PLs & 35515 & 0.33 & 26195 & 0.25 & 26604 & 0.24 & 1.29 & 0.97 & 1.99 & 0.53 \\
\hline & $2+\mathrm{PLs}$ & 40702 & 0.42 & 38697 & 0.41 & $17 \mid 22$ & 0.20 & 0.13 & 0.71 & 0.82 & 0.28 \\
\hline & $2-2+\mathrm{PLs}$ & 37170 & 0.36 & $3774 \mid$ & 0.33 & 23920 & 0.23 & 1.05 & 0.76 & 1.79 & 0.15 \\
\hline & 3PLs & 29588 & 0.29 & 20874 & 0.19 & 29812 & 0.31 & 1.82 & 1.91 & 3.32 & 3.50 \\
\hline & 4PLs & 24823 & 0.22 & 24957 & 0.21 & $146 \mid 6$ & 0.12 & 0.21 & 0.56 & 0.59 & 1.25 \\
\hline & 3-4PLs & 28109 & 0.27 & 22694 & 0.20 & 25868 & 0.26 & 1.96 & 2.21 & 4.64 & 5.50 \\
\hline \multirow[t]{6}{*}{ Current Assets } & 2PLs & 29883 & 0.26 & 24314 & 0.25 & 13223 & 0.07 & 1.27 & 2.18 & 0.83 & 5.50 \\
\hline & $2+\mathrm{PLs}$ & 24675 & 0.26 & 24698 & 0.24 & 6734 & 0.07 & 0.44 & 1.75 & 1.17 & 3.64 \\
\hline & 2-2PLs & 28221 & 0.26 & 24698 & 0.24 & 11733 & 0.07 & 1.50 & 1.99 & 1.98 & 4.44 \\
\hline & 3PLs & 35955 & 0.32 & 26026 & 0.25 & 31148 & 0.28 & 2.57 & 3.87 & 6.83 & 16.02 \\
\hline & 4PLs & 33693 & 0.30 & 25070 & 0.30 & 17645 & 0.10 & 0.94 & 0.50 & 0.81 & 0.55 \\
\hline & 3-4PLs & 35253 & 0.31 & 25070 & 0.26 & 27358 & 0.23 & 2.60 & 4.26 & 7.76 & 20.52 \\
\hline \multirow[t]{6}{*}{ Stock \& W.I.P. } & 2PLs & 421 & 0.004 & 328 & 0.003 & 360 & 0.004 & 1.69 & 2.43 & 2.88 & 7.45 \\
\hline & $2+\mathrm{PLs}$ & 703 & 0.008 & 591 & 0.006 & 497 & 0.007 & 1.58 & 1.79 & 2.02 & 3.53 \\
\hline & $2-2+\mathrm{PLs}$ & 511 & 0.005 & 381 & 0.004 & 424 & 0.005 & 1.67 & 2.26 & 2.77 & 6.09 \\
\hline & 3PLs & 740 & 0.008 & 348 & 0.003 & 1594 & 0.020 & 4.10 & 4.16 & 17.40 & 17.87 \\
\hline & 4PLs & 2588 & 0.020 & 500 & 0.004 & 5947 & 0.043 & 2.98 & 2.93 & 8.90 & 8.69 \\
\hline & 3-4PLs & 1313 & 0.012 & 388 & 0.003 & 3547 & 0.029 & 4.46 & 3.67 & 20.93 & 13.26 \\
\hline \multirow{6}{*}{ Working Capital } & 2PLs & 4810 & 0.039 & 3306 & 0.030 & 11734 & 0.105 & 1.56 & 1.38 & 3.28 & 2.62 \\
\hline & $2+\mathrm{PLs}$ & -407 & 0.002 & -545 & -0.006 & 7714 & 0.079 & 0.12 & 0.55 & 0.39 & 0.31 \\
\hline & $2-2+P L s$ & $3 \mid 44$ & 0.028 & 701 & 0.007 & $108 \mid 4$ & 0.098 & 1.54 & 1.32 & 3.88 & 2.70 \\
\hline & 3PLs & 8269 & 0.076 & 1984 & 0.020 & 27964 & 0.280 & 3.32 & 3.79 & 12.78 & 15.69 \\
\hline & 4PLs & 9485 & 0.064 & 4628 & 0.035 & 15886 & 0.122 & 1.20 & 0.51 & 0.68 & 0.15 \\
\hline & 3-4PLs & 8646 & 0.073 & 2459 & 0.023 & 24557 & 0.240 & 3.26 & 4.01 & 13.40 & 18.88 \\
\hline
\end{tabular}

Table $2 \mathrm{~B}$ reports the results of the Leven's statistics (W) to test the equality of variances assumption. ${ }^{100}$

Table 2B. Levene's tests for homogeneity of variances.

\begin{tabular}{|c|c|c|c|c|c|c|}
\hline & \multicolumn{2}{|c|}{ Levene4 (W) } & \multicolumn{2}{|c|}{ Levene3 (W) } & \multicolumn{2}{|c|}{ Levene2 (W) } \\
\hline \multicolumn{7}{|c|}{ Economic/Financial Indicators } \\
\hline $\begin{array}{l}\text { Turnover } \\
\text { Op. Prof. } \\
\text { Cash In Op. Act. } \\
\text { ROCE }\end{array}$ & $\begin{array}{l}0.84 ; 0.94 \\
0.04 ; 0.08 \\
0.19 ; 0.57 \\
0.00 ; 0.07\end{array}$ & & $\begin{array}{l}0.72 ; 0.85 \\
0.06 ; 0.1 \\
0.18 ; 0.49 \\
0.25 ; 0.26\end{array}$ & & $\begin{array}{l}0.96 ; 0.94 \\
0.7 ; 0.9 \\
0.15 ; 0.18 \\
0.05 ; 0.22\end{array}$ & \\
\hline \multicolumn{7}{|c|}{ Non-Economic/Financial Indicators } \\
\hline $\begin{array}{l}\text { n. Employees } \\
\text { Fixed Assets } \\
\text { Tangible Assets } \\
\text { Current Assets } \\
\text { Stock \& W.I.P. } \\
\text { Working Cap. }\end{array}$ & $\begin{array}{l}0.00 ; 0.06 \\
0.06 ; 0.30 \\
0.20 ; 0.49 \\
0.27 ; 0.18 \\
0.00 ; 0.10 \\
0.09 ; 0.36\end{array}$ & $\begin{array}{l}0.06 ; 0.28 \\
0.15 ; 0.41 \\
0.07 ; 0.32 \\
0.00 ; 0.19 \\
0.25 ; 0.49\end{array}$ & $\begin{array}{l}0.00 ; 0.03 \\
0.14 ; 0.41 \\
0.31 ; 0.54 \\
0.01 ; 0.09 \\
0.07 ; 0.50 \\
0.06 ; 0.22\end{array}$ & $\begin{array}{l}0.29 ; 0.65 \\
0.51 ; 0.79 \\
0.04 ; 0.21 \\
0.04 ; 0.44 \\
0.15 ; 0.33\end{array}$ & $\begin{array}{l}0.003 ; 0.06 \\
0.74 ; 0.99 \\
0.53 ; 0.58 \\
0.01 ; 0.05 \\
0.00 ; 0.13 \\
0.02 ; 0.11\end{array}$ & $\begin{array}{l}0.96 ; 0.63 \\
0.72 ; 0.54 \\
0.02 ; 0.06 \\
0.00 ; 0.12 \\
0.09 ; 0.19\end{array}$ \\
\hline
\end{tabular}

NB the value in the cells is the $p$ value of the Levene's test.

This assumption holds for the majority of the variances. 